\title{
Impact of Salespeoples' Entrepreneurial Behavior toward Customer Satisfaction, Trust, Commitment, and Loyalty
}

\author{
R. A. Putri Tri Widyaningrum \\ Universitas Indonesia Jakarta, \\ Indonesia \\ putritriwidyaningrum@gmail.com
}

\author{
Rizal Edy Halim \\ Universitas Indonesia \\ Jakarta, Indonesia \\ rizaledy@gmail.com
}

\begin{abstract}
The past 10 years has witnessed a dramatic shift in customer's orientation from goods-dominant to servicedominant logic (Vargo, Merz, He, \& Vargo, 2014). Salespeople not only sell a product or service, but also focus on helping customers to make the right decision to buy a satisfactory product or service (Singh \& Koshy, 2012). Salespeople's entrepreneurial behavior, such as innovativeness, proactiveness, and risk taking (Amyx, Bhuian, \& Shows, 2016), helps a company to increase sales and foster customer relationships. The present study aims to examine the impact of salespeoples' entrepreneurial behavior on customer satisfaction, trust, commitment, and loyalty. This impact in the context of banking industry is examined using structural equation model. The study results found that salespeople's entrepreneurial behavior affected customer satisfaction, trust, commitment, and loyalty.
\end{abstract}

Keywords-entrepreneurial behaviors, customer satisfaction, trust, commitment, loyalty

\section{INTRODUCTION}

In the last decades, customer orientation has dramatically shifted [1] from goods-dominant to service-dominant logic [2]. In customer oriented company, salespeople help a customer to make a satisfactory buying decision by not only selling the product [1] or chasing sales number [3], but more by establishing a long-term relationship and sustained communication with a costumer [4]. It is not only a shortterm transactional relationship but also a long-term customer relationship [5].

Among financial institutions, banks play a key role in the economic growth and stability [6]. Kaura [7] asserts that banks, as the backbone of economy, should anticipate and fulfill customer needs. In the highly competitive business scenario in the service industry, it is essential that banks are customer oriented. They should maintain their customer base to enhance and establish a long-term relationship. Banks can enhance their competitive edge and provide high returns to shareholder by understanding the needs and providing better value to customers [8].

Following the studies by Amyx, Bhuian, \& Shows [9], the present study uses customer service as the subject of research because we believe that salespeople and customer service persons as bank frontline essentially play the same role. Salespeople provide information, understanding, and fulfill customer needs and establish a long-term relationship [1]. They identify customer needs and pro-actively provide the right innovative solution [10], They take the necessary risk to surpass customer expectation [9]. As frontline, they also provide service, achieve sales target, establish and maintain long-term relationship with costumers [11], provide reliable and efficient, product knowledge, are proactive, are capable of identifying opportunities and close sales, risk taking, flexible to uncertainty, and take initiative to identify problems and find the solutions [12]. Based on this similarity, the present study aims at customer service as one of bank's frontliner that is required to provide service, achieve the target, give solutions, be proactive, and take risks.

Christopher and Wirtz [13] revealed that the quality of employees plays a key role in service companies. Success in the banking industry depends on customer satisfaction [7], concerns customer trust and commitment [14], and maintains the customer loyalty [15]. Companies that could fulfill and exceed customer expectation would create future potential business [16]. A customer believing that a company can deliver as promised and will act in the interest of customer will increase customer loyalty [17]. Positive customer experience and fulfillment of commitment to customers will enhance customer loyalty; however, a negative experience would lead to loss of consumer loyalty [4] and customer trust [18].

Customer satisfaction is extremely important to enhance customer loyalty. A loyal customer will recommend to others and repurchase [16, 19]. Maintaining an existing customer is cheaper than finding a new one [3, 7, 19]. Customer satisfaction has a positive effect on customer loyalty $[17,20]$. However, Moreira and Silva [21] revealed that customer satisfaction has no significant effect on loyalty, even though satisfied, a customer might be stop using the service and feels no bonding with the company.

According to Gaur, Sharma, Herjanto \& Kingshott [22], frontline experience and capability could convince and enhance customer satisfaction, which leads to customer commitment. Professional bankers influence customer satisfaction and loyalty [19]. As part of human capital, personality will influence individual productivities, including entrepreneurial ability [23]. The relationship between a customer and salespeople might become an important factor influencing customer buying decision, but only a few studies have evaluated this relationship [24]. The potential role of salespeople's entrepreneurial behavior has been overlooked [9].

This study examines the effect of salespeople's entrepreneurial behavior on customer satisfaction, trust, and 
commitment to the salespeople and customer loyalty to the banking industry. It confirms that entrepreneurial behavior helps a firm to maintain a long-term relationship with a customer through customer satisfaction, trust, commitment, and loyalty. This study is important because it helps a firm to develop entrepreneurial behavior such as innovativeness, pro-activeness, and risk-taking ability [9] of customer service to achieve customer satisfaction, trust, commitment, and loyalty.

\section{ANALYTICAL FRAMEWORK}

This research tests five hypotheses. Salespeople's entrepreneurial behaviors have a positive effect on customer satisfaction. Customer satisfaction has a positive effect on customer trust. Customer satisfaction has a positive effect on customer commitment. Customer trust has a positive effect on customer loyalty. Customer commitment has a positive effect on customer loyalty.

\section{A. Salespeople's entrepreneurial behavior and satisfaction}

Entrepreneurs are those who organize, manage, and estimate risk [25, 26]. Entrepreneurs seek, react, and maximize the opportunities [27], independent, creative, have ambition and courage [28]. Noteworthy entrepreneur characteristics are determination and perseverance, a drive to achieve, opportunity oriented, creativity and innovation, tolerance for ambiguity, calculated risk taking, high energy level, vision, passion, and internal locus of control [25]. This study based on previous research by Amyx, Bhuian, \& Shows [9] reveals that innovativeness, pro-activeness, and risk taking reflect salespeople's entrepreneurial behavior.

Innovativeness refers to creating or developing products or service as a solution [9] and meet customers' needs and desire [25] or introduce new products or production methods based on new technology [29]. Pro-activeness refer to how salespeople provide solutions to customers' problems and give more value than competitors [9]. Risk taking means the ability to calculate the risks [25], use resources to take opportunity [9], be prepared to react, and take responsible for possibility of failure [30].

Salespeople's entrepreneurial behaviors have a positive influence on customer satisfaction [9]. In banks, employee behavior has a positive impact on customer satisfaction [7]. Service capability reduces uncertainty in customer and increases their satisfaction [22]. Professional banking has an impact on customer satisfaction and loyalty [19]. Efficient customer service meets customer needs and wants, provides the best solution for customer, and enhances customer satisfaction through risk taking. Customer service provides a product to meet customer satisfaction needs improvement. We believe that salespeople with entrepreneurial attitudes can improve customer satisfaction.

H1 Salespeople's entrepreneurial behaviors have a positive effect on customer satisfaction

A customer feels satisfied when the product exceeds customer expectations [31]. Customer satisfaction is defined as feelings of pleasure or disappointment toward product performance as compared to his expectations [32]. This is the stage of customer evaluation of service performance based on experience compared to customer expectations [13]. Walter, Mueler, and Helfert [18] and Amyx et al. [9] confirmed that customer satisfaction is the comparison of post-purchase evaluations and after-use expectations.

Trust is a combination of integrity, certainty, and a positive relationship between parties [21]. Morgan and Hunt [5] revealed that trust is the confidence in the reliability and integrity of partners. Walter et al. [18] defined that customer trust as customer's belief toward attitude, honesty, and competence to action a relationship desired. Trust is divided by credibility and benevolence trust. Credibility trust is customer's belief in employee's ability, service, expertise, and capability [33] and ability to keep promises [17]. Benevolence trust is a belief that a company is able to meet the customer needs [33] and interest [17]. Trust occurs not only from mutual relationship [15], but also on emotion for long-term relationship [34]. Sumaedi et al. [14] claim that customer's trust is the confidence in the bank, where the bank will act according to customers' expectation.

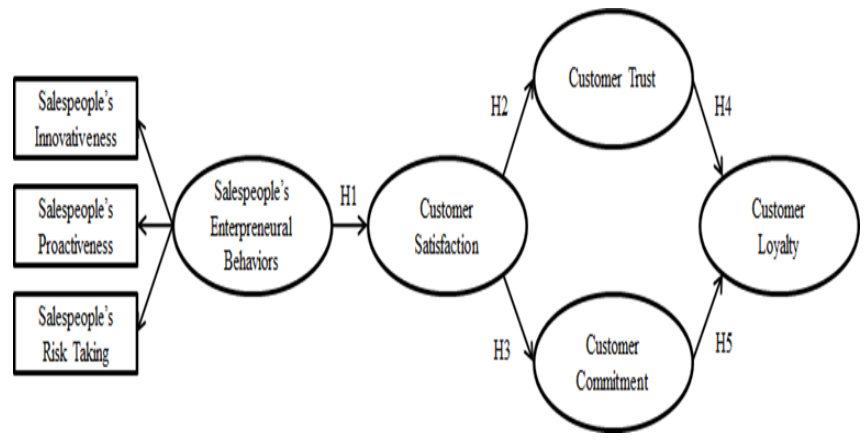

Fig. 1. Customer Satisfaction towards Customer Satisfaction, Trust, Commitment and Loyalty

The more satisfied is a consumer with the supplier in a previous relationship, the more is the consumer's belief in the next relationship [18]. Customer trust is the result of the entrepreneurial ability of salespeople [9]. In banks, trust refers to the overall consumer satisfaction based on experience [17]. Consumers with bad experiences can lose their trust [35]. Trust is the result of a sense of satisfaction from a previous experience. The ability of the salespeople in providing solutions to customer needs and desires improves customer trust. Therefore, the following hypothesis:

H2 Customer satisfaction has a positive effect on customer trust

Morgan and Hunt [5] defined commitment as belief between parties, in which relationship is important and deserves to be maintained. They also proposed that commitment is an exchange relationship between parties to get value for themselves and they have to build and maintain the relationship. Each party maintains the existing relationship. Companies that succeed in fulfilling their customer's expectations or exceed in expected satisfaction will create future business potential [16]. Customer commitment is developed by good relationship and strong bonding [36]. It is binding on a customer to continue the purchase without considering the type of commitment [37]. Companies that give value from the customer point of view will benefit more and have good relations with their customers [4]. The dimensions of commitment are affective commitment, which is the result of positive experience when relationship is developed between customers and company; instrumental commitment occurs when there are investments 
such as time and other resources to build a relationship; temporal commitment shows the existence of a relationship $[9,18]$; and continuance commitment is based on advantage or disadvantage that is offered by the company and the consequences if the relationship ceases [15].

Satisfied customers will repurchase and inform others of their good experiences [32]. Commitment is a relationship between parties to derive value for themselves and build and maintain that relationship [5]. Dimitriades [38] revealed in his research that satisfaction positively affects commitment. Service capabilities not only reduce consumer hesitation but also increase customer satisfaction, which improve customer commitment [22]. In the context of a bank, customer satisfaction is the result of a previous experience, both of products used or toward salespeople. Based on this, the next hypothesis follows:

H3 Customer satisfaction has a positive effect on customer commitment

\section{B. Customer trust and commitment toward loyalty}

Loyalty is a deep sense of customer commitment to continue the special relationship [39] for long-term as well as recommend to others [13]. Customer loyalty increases company's profit [13], reduces cost [40], and adds value to the company [41]. Customer loyalty consists of behavioral and attitudinal loyalty. Behavioral loyalty is the purchase loyalty [38] and normally is conditioned by customer satisfaction [42] or customer habit or there are no many choices for the customer [33]. Attitudinal loyalty emphasizes positive evaluation of the company $[35,42]$ and the emotional relationship between customer and company [33]. McMullan and Gilmore [43] revealed that customer loyalty is focused on the number of purchase (behavioral loyalty) and affected by circumstances (situational loyalty).

Trust leads to loyalty [21]; so if the level of trust is high, customers will purchase more bank products and be more loyal to the bank [35]. In building trust, consumers feel the positive results and believe that these results will continue in the future, where trust affects loyalty [17]. Customer loyalty to retail banks depends heavily on trust and satisfaction [44]. Thus follows the hypothesis:

H4 Customer trust has a positive effect on customer loyalty

Kaura and Sharma Sourabh [19] revealed that customer loyalty is a combination of customers' favorable attitude and behavior and customers recommending the product/service and repurchase from the company. Bounded indicates that customer loyalty is getting stronger [38]. Higher customer relationship commitment leads to higher customer loyalty, and customer in turn would recommended the product [22]. Good relationship encourages a customer to purchase another product from the bank. Customer attachment to salespeople or to bank leads the customer to recommend the bank to their partners or family. Based on this, the following hypothesis is framed:

H5 Customer commitment has a positive effect on customer loyalty

\section{METHODOLOGY}

\section{A. Sample}

The population of the present study includes customers of banking service in Indonesia. The samples are the customers who have communicated with customer service in banking branch during the past 3 months. The respondents of the online survey were the customers of funding banking. Total of 203 of 253 respondents were found eligible for this survey. Primary data were collected by distributing selfadministered questionnaires. The structured questionnaire adopted the Likert scale to determine the level of agreement or disagreement from each statement on 6-point scale because respondents in Asia usually tend to choose neutral points, so scaling with more (fewer) points or without midpoints would be better [45].

\section{B. Measure}

Based on Figure 1, the variables of salespeople entrepreneurial behavior, customer satisfaction, trust, and commitment were adapted from Amyx et al. [9] and customer loyalty was adapted from Moreira and Silva [21]. We used a structural equation model (measurement and structural model) to analyze the research. Measurement model use confirmatory model analysis (CFA) consists of salespeople entrepreneurial behavior ( 9 indicators), customer satisfaction ( 3 indicators), customer trust (4 indicators), customer commitment ( 3 indicators), and customer loyalty ( 3 indicators). The fit indices moderately fit because one of the standard loading factors is less than 0.7 . We deleted one item of indicator customer trust, CT1; "Customer service of Bank X only promotes what I need". We believed that the other indicators: "Customer service of Bank X provides product according to needs" has the same meaning. Fit indices reflect good fit after re-specification model: $\chi^{2}=482.615$, df $=175$, TLI $=0.908$, CFI $=0.924$, IFI $=0.924$ and $\mathrm{RMSEA}=0.093$. The $t$-value range is 10.297 to 19.644 , greater than 1.96 , significant at $\mathrm{p}<0.05$ (Table 1 ).

Convergent validity measured by composite reliability (CR) based on loading factor $\geq 0.7$ and average variance extracted (AVE) $\geq 0.5$ [46]. All indicators of salespeople's entrepreneurial behavior, customer satisfaction, trust, commitment, and loyalty had good validity, CR was more than $0.7 ; 0.936,0.894,0.842,0.898,0.895$. Correlation between variables showed a positive result less than 1 , indicating the feasibility of parameter estimation and AVEs were $0.677,0.739,0.640,0.746,0.741$. Table 2 shows the result of CR and AVE

TABLE I.

\begin{tabular}{llllll}
\hline & Loyalty & Trust & Commitment & Satisfaction & SEB \\
\hline Loyalty & 1 & & & & \\
Trust & 0.599 & 1 & & & \\
Commitment & 0.733 & 0.629 & 1 & & \\
Satisfaction & 0.837 & 0.731 & 0.693 & 1 & 1 \\
SEB & 0.873 & 0.747 & 0.753 & 0.938 & 1 \\
\hline
\end{tabular}

Notes: Loyalty-customer loyalty; Trust-customer trust; Commitmentcustomer commitment; Satisfaction-customer satisfaction; SEB-salespeople Entrepreneurial behavior 
TABLE II.

\begin{tabular}{|c|c|c|c|c|c|}
\hline Variable & $\begin{array}{c}\mathrm{t}- \\
\text { value }\end{array}$ & $\begin{array}{c}\text { Std } \\
\text { loading }\end{array}$ & $\begin{array}{c}\text { Std } \\
\text { Loading2 }\end{array}$ & CR & AVE \\
\hline \multicolumn{6}{|c|}{$\begin{array}{c}\text { Salespeople } \\
\text { Entrepreneurial } \\
\text { Behavior } \\
\end{array}$} \\
\hline I1 & & 0.7 & 0.49 & 0.93604 & 0.67701 \\
\hline I2 & 11.23 & 0.817 & 0.668 & & \\
\hline I3 & 14.066 & 0.763 & 0.583 & & \\
\hline P1 & 11.354 & 0.835 & 0.697 & & \\
\hline $\mathrm{P} 2$ & 10.297 & 0.755 & 0.571 & & \\
\hline P3 & 11.24 & 0.83 & 0.688 & & \\
\hline $\mathrm{R} 1$ & 11.768 & 0.869 & 0.756 & & \\
\hline $\mathrm{R} 2$ & 11.73 & 0.867 & 0.751 & & \\
\hline R3 & 11.344 & 0.833 & 0.694 & & \\
\hline \multicolumn{6}{|c|}{$\begin{array}{c}\text { Customer } \\
\text { Satisfaction }\end{array}$} \\
\hline CS1 & & 0.894 & 0.799 & 0.89422 & 0.73935 \\
\hline CS2 & 13.232 & 0.759 & 0.576 & & \\
\hline $\mathrm{CS} 3$ & 19.644 & 0.918 & 0.842 & & \\
\hline \multicolumn{6}{|c|}{ Customer Trust } \\
\hline $\mathrm{CT} 2$ & 10.541 & 0.73 & 0.533 & 0.84172 & 0.64046 \\
\hline CT3 & 12.941 & 0.867 & 0.752 & & \\
\hline CT4 & & 0.798 & 0.636 & & \\
\hline \multicolumn{6}{|c|}{$\begin{array}{c}\text { Customer } \\
\text { Commitment }\end{array}$} \\
\hline $\mathrm{CC} 1$ & & 0.795 & 0.632 & 0.89755 & 0.74576 \\
\hline $\mathrm{CC} 2$ & 13.929 & 0.855 & 0.731 & & \\
\hline $\mathrm{CC} 3$ & 14.668 & 0.935 & 0.874 & & \\
\hline \multicolumn{6}{|l|}{$\begin{array}{l}\text { Customer } \\
\text { Loyalty }\end{array}$} \\
\hline CL1 & 14.019 & 0.801 & 0.641 & 0.89517 & 0.74056 \\
\hline CL2 & 17.819 & 0.913 & 0.834 & & \\
\hline CL3 & & 0.864 & 0.747 & & \\
\hline
\end{tabular}

Notes: I1, CS1, CT4, CC1, CL3 were fixed to 1.0 to satisfy the requirement.

\section{RESUTT}

We compute the structural model in Amos to test all the variables such as salespeople's entrepreneurial behavior, customer satisfaction, customer commitment, customer trust, and customer loyalty. The goodness-of-fit indicates marginal fit; $\chi^{2}=571.061$, df $=180$, TLI $=0.887$, CFI $=0.903$, IFI $=$ 0.904 , and RMSEA $=0.104$. The test result supported H1, $\mathrm{H} 2, \mathrm{H} 3, \mathrm{H} 4$, and $\mathrm{H} 5$. Table 3 shows the result.

As we predicted that entrepreneurial behavior positively and significantly correlates to customer satisfaction $(t$-value $=11.621, \mathrm{CR}=0.969, \mathrm{p}<0.05)$, it supports the first hypothesis. This result is consistent with the previous studies, which stated that entrepreneurial behavior has a positive relationship with customer satisfaction $[9,12]$. Consistent with the second hypothesis, customer satisfaction is positively and significantly related to customer trust ( $\mathrm{t}$-value $=10.79, \mathrm{CR}=0.809, \mathrm{p}<0.05$ ).

The higher the level of customer satisfaction, the higher the customer's trust [17, 18, 21, 35. Dimitriades [38] and Gaur et al. [22] suggested that customer satisfaction is positively and significantly related to customer commitment (t-value $=10.55, \mathrm{CR}=0.77, \mathrm{p}<0.05)$, which supports the third hypothesis. As expected, customer trust is positively and significantly related to customer loyalty (t-value $=3.62$, $\mathrm{CR}=0.34, \mathrm{p}<0.05$ ), which supports the fourth hypothesis.

This result is consistent with the previous research that suggested customer's trust is related to customer loyalty [17, $21,35]$. Finally, in line with the previous studies by Dimitriades [38] and Gaur et al. [22], customer commitment is positively and significant related to customer loyalty, thus the fifth hypothesis is accepted ( $\mathrm{t}$-value $=6.13, \mathrm{CR}=0.55, \mathrm{p}$ $<0.05)$.

TABLE III.

\begin{tabular}{|l|c|c|c|c|}
\hline Fit indices & $\begin{array}{c}\text { Measurement } \\
\text { model }\end{array}$ & $\begin{array}{c}\text { Structural } \\
\text { model }\end{array}$ & & \\
\hline$x^{2}$ & 482.615 & 571.061 & & \\
\hline $\mathrm{df}$ & 175.00 & 180 & & \\
\hline $\mathrm{TLI}$ & 0.908 & 0.887 & & \\
\hline CFI & 0.924 & 0.903 & & \\
\hline IFI & 0.924 & 0.904 & & \\
\hline RSMEA & 0.093 & 0.104 & & \\
\hline \multicolumn{1}{|c|}{ Paths } & $\mathrm{t}$-value & $\mathrm{CR}$ & $\mathrm{p}$ & Result \\
\hline $\begin{array}{l}\text { SEB- } \\
\text { Satisfaction }\end{array}$ & 11.621 & 0.969 & $* * *$ & Supported \\
\hline $\begin{array}{l}\text { Satisfaction - } \\
\text { Trust }\end{array}$ & 10.793 & 0.809 & $* * *$ & Supported \\
\hline $\begin{array}{l}\text { Satisfaction - } \\
\text { Commitment }\end{array}$ & 10.546 & 0.767 & $* * *$ & Supported \\
\hline $\begin{array}{l}\text { Trust- } \\
\text { Loyalty }\end{array}$ & 3.624 & 0.338 & $* * *$ & Supported \\
\hline $\begin{array}{l}\text { Commitment } \\
\text {-Loyalty }\end{array}$ & 6.129 & 0.551 & $* * *$ & Supported \\
\hline $\begin{array}{l}\text { Notes: Loyalty-customer loyalty; Trust-customer trust; Commitment- } \\
\text { customer commitment; Satisfaction-customer satisfaction; SEB- } \\
\text { salespeople Entrepreneurial behavior }\end{array}$ \\
\hline
\end{tabular}

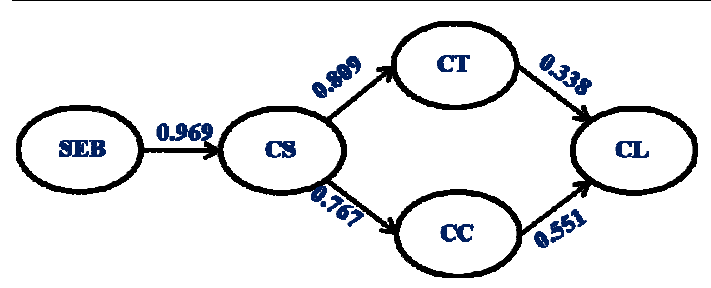

Fig. 2. Impact of Salespeople's Entrepreneurial Behavior toward Customer Satisfaction, Trust, Commitment, and Loyalty

\section{DISCUSSION AND IMPLICATION}

In the technology era, banking industry has experienced a transformation in service delivery and digital technology, for example, customer relation management and electronic banking (ATM, internet banking, mobile banking). According to Andreini, Salo, Wendelin, Pezzotta and Gaiardelli [47], transformation and standardization of service 
and product could drive away the relationship between bank and customer. A customer may feel that the bank only offers the product and not the required solution and concerned only with transactional approach. Therefore, customer service ability and capability need to be improved on the relationship through entrepreneurial behavior. This study helps a manager to have a better understanding of the important roles of entrepreneurial behavior.

The present study verifies that entrepreneurship of customer service is influenced by the customer satisfaction, trust, commitment, and loyalty. Based on Amyx et al. [9], salespeople's entrepreneurial behavior in this study consisted of nine indicators representing innovative, proactive, and risk taking. To be innovative, customer service must provide product and service according to the customer needs. To be proactive, customer service offers a better solution, provides new experiences, and becomes superior compared to competitors. Risk-taking customer service should be able to take a chance in winning the opportunities. The study result also proves that by having this attitude, customer service could improve customer satisfaction, trust, commitment, and loyalty.

Salesperson who is customer oriented will help a costumer to make the right purchasing decisions [1] Frontline salespersons provide services in order to achieve target sales, build and maintain long-term relationships with customer [11], and provide value to the customers [48]. The study results are in accordance with the previous research of $\mathrm{T}$. Yu et al. [12], who explained that service sales have a positive relationship with customer satisfaction and financial performance as a measure of banking branch performance. According to this result, customer service must have product knowledge, take risk, be proactive, and be able to identify opportunities and close the sales.

Entrepreneurial behavior gives a customer heightened customer satisfaction. With regard to bank branch, customer who needs information on banking product is expected to get the product fit to their needs. Customer service is not only about the product sales, but it must also ensure that the product is suitable to the customer need. Customer would be satisfied if banking service gives the solution to their problems.

Customer satisfaction leads to customer trust and commitment. Trust refers to overall customer satisfaction based on their experience [17]. If a customer is highly satisfied customer in a previous relationship, they trust the next relationship [18]. Customers who have had bad experience will lose their trust [35]. Customer who is satisfied with the customer service would increase their trust; otherwise, they would not trust the customer service or the bank. This could be very important to maintain customer trust by impressing the customer, providing best solution, and giving accurate information. A customer would maintain the relationship with customer service if they feel they are treated like a good friend and believe that the relationship is worth being maintained.

Customer trust and commitment have a positive effect on customer loyalty. Customers who believe that a company can provide as promised and based on their interest will increase their loyalty toward the company [17]. Trust will drive the customer to buy more of the product and be loyal to the bank [35]. Trust is one of the important factors in banking industry. Customer would be loyal to a bank, if the bank could deliver as promised. A customer would recommend the same to their friends or families. Committed customers will build relationships continuously with the bank and increase their loyalty. Customers would continue their financial activities in that bank if they feel bounded to customer service and the bank.

Competition in banking industry relies on service and sales. The study results show that some concerns need to be addressed by the management. Service sales are positively related to bank performance, customer satisfaction, and financial performance [12]. As the frontliners, customer service should have the ability to provide excellent service and the capability to sell a product. Management has to encourage customer service to nurture entrepreneurial behavior. They need to increase the awareness about the importance of emotional bonding and maintain long-term relationship. An appreciation program needs to be evaluated to motivate an employee and improve their frontliner ability.

\section{LIMITATION AND FUTURE RESEARCH}

The present study only adopts quantitative research method. Further, quantitative and qualitative research methods with focus discussion group would help in achieving deeper understanding on the customer perception of this research objective. The other limitation is that respondents are grouped as funding banking customers. Further, groups based on funding as retail and priority customer must be included to understand the expectation from each group to improve satisfaction, trust, commitment, and loyalty. Even though we believed that salespeople and customer service has a similar role, in this research only customer service at a bank branch was considered, while salespeople might be actively approaching customers even outside the office.

\section{REFERENCES}

[1] Singh, R., \& Koshy, A. (2012). A new conceptualization of salesperson's customer orientation. Marketing Intelligence \& Planning, 30(1), 69-82. doi:10.1108/02634501211193921

[2] Vargo, S. L., Merz, M. A., He, Y., \& Vargo, S. L. (2009). The evolving brand logic: A service-dominant logic perspective. Journal of the Academy of Marketing Science, 37(3), 328-344. doi:10.1007/s11747-009-0143-3

[3] Colwell, S., Hogarth-Scott, S., Jiang, D., \& Joshi, A. (2009). Effects of organizational and serviceperson orientation on customer loyalty. Management Decision, 47(10), 1489-1513. doi: 10.1108/00251740911004655

[4] Ghandehary, M., Harati, H., \& Pool, J. K. (2014). Identifying and ranking the effective factors on customer values: A FAHP approach towards Sepah Bank, Iran. Education, Business and Society: Contemporary Middle Eastern Issues, 7(1), 57-74. doi: 10.1108/EBS04-2013-0009

[5] Morgan, R. M., \& Hunt, S. D. (1994). The commitment-trust theory of relationship marketing. Journal of Marketing, 58(3), 20. doi: $10.2307 / 1252308$

[6] Fungáčová, Z., Hasan, I., \& Weill, L. (2017). Trust in banks. Journal of Economic Behavior and Organization. doi: 10.1016/j.jebo.2017.08.014

[7] Kaura, V. (2013). Antecedents of customer satisfaction: A study of Indian public and private sector banks. International Journal of Bank Marketing, 31(3), 167-186. doi: 10.1108/02652321311315285

[8] Padmavathy, C., Balaji, M. S., \& Sivakumar, V. J. (2012). Measuring effectiveness of customer relationship management in Indian retail banks. International Journal of Bank Marketing, 30(4), 246-266. doi: $10.1108 / 02652321211236888$ 
[9] Amyx, D., Bhuian, S. N., \& Shows, G. D. (2016). Customersalespeople relationship. Marketing Intelligence \& Planning, 34(5), 586-604. doi: 10.1108/MIP-09-2015-0170

[10] Moghareh Abed, G., \& Haghighi, M. (2009). The effect of selling strategies on sales performance. Business Strategy Series, 10(5), 266282. doi: 10.1108/17515630910989169

[11] Woo, K. S. \& Ennew, C. (2006). Business-to-business relationship quality: An IM interaction-based cpnceptualization and measurement. European journal of marketing, 38(9/10), 1252-1271. doi:10.1108/03090560410548960

[12] Yu, T., Patterson, P., \& de Ruyter, K. (2015). Converting service encounters into cross-selling opportunities. European Journal of Marketing, 49(3/4), 491-511. doi:10.1108/EJM-10-2013-0549

[13] Christopher, L., \& Wirtz, J. (2018). Essentials of services marketing (yajnaseni das, Ed.) (3rd ed.). England: Pearson Education.

[14] Sumaedi, S., Juniarti, R. P., \& Bakti, I. G. M. Y. (2015). Understanding trust \& commitment of individual saving customers in Islamic banking. Journal of Islamic Marketing, 6(3), 406-428. doi:10.1108/JIMA-06-2013-0045

[15] Izogo, E. E., Reza, A., Ogba, I.-E., \& Oraedu, C. (2017). Determinants of relationship quality and customer loyalty in retail banking: Evidence from Nigeria. African Journal of Economic and Management Studies, 8(2), 186-204. doi: 10.1108/AJEMS-01-20160011

[16] Gerhard raab, R. (2010). Customer Relationship Management.

[17] Yap, B. W., Ramayah, T., \& Wan Nushazelin, W. S. (2012). Satisfaction and trust on customer loyalty: A PLS approach. Business Strategy Series, 13(4), 154-167. doi:10.1108/17515631211246221

[18] Walter, A., Mueler, T. A., \& Helfert, G. (2000). The impact of satisfaction, trust, and relationship value on commitment: Theoretical Considerations and empirical results. The 16Th IMP Conference, 118.

[19] Kaura CH, V., \& Sharma Sourabh, S. D. P. (2006). Service quality, service convenience, price and fairness, customer loyalty, and the mediating role of customer satisfaction. International Journal of Bank Marketing, 33(4), 404-422. doi: 10.1108/09564230910978511

[20] Santouridis, I., \& Trivellas, P. (2010). Investigating the impact of service quality and customer satisfaction on customer loyalty in mobile telephony in Greece. The TQM Journal, 22(3), 330-343. doi:10.1108/17542731011035550

[21] Moreira, A. C., \& Silva, P. M. (2015). The trust-commitment challenge in service quality-loyalty relationships. International Journal of Health Care Quality Assurance, 28(3), 253-266. doi: 10.1108/IJHCQA-02-2014-0017

[22] Gaur, S. S., Sharma, P., Herjanto, H., \& Kingshott, R. P. J. (2017). Impact of frontline service employees' acculturation behaviors on customer satisfaction and commitment in intercultural service encounters. Journal of Service Theory and Practice, 27(6), 11051121. doi: 10.1108/JSTP-08-2016-0138

[23] Viinikainen, J., Heineck, G., Böckerman, P., Hintsanen, M., Raitakari, O., \& Pehkonen, J. (2017). Born entrepreneurs? Adolescents' personality characteristics and entrepreneurship in adulthood. Journal of Business Venturing Insights, 8, 9-12. doi:10.1016/j.jbvi.2017.05.001

[24] Yu, T.-W., \& Tseng, L.-M. (2016). The role of salespeople in developing life insurance customer loyalty. International Journal of Retail \& Distribution Management, 44(1), 22-37. doi:10.1108/IJRDM-06-2014-0074

[25] Kuratko, D. F. (2014). Entrepreneurship: Theory, process, practice, 9th edition. (J. Erin, Ed.), Journal of Engineering Education (9th ed., Vol. 98). doi: 658.421

[26] Mullins, J. (2017). The counter-conventional mindsets of entrepreneurs. Business Horizons, 60(5), 597-601. doi: 10.1016/j.bushor.2017.05.003

[27] Drucker, P. F. (2006). Innovation and Entrereneurship. Business.

[28] Kirkley, W. W. (2016). Entrepreneurial behaviour: The role of values. International Journal of Entrepreneurial Behavior \& Research, 22(3), 290-328. doi: 10.1108/IJEBR-02-2015-0042

[29] Lau, T. L. M., Shaffer, M. A., Fai Chan, K., \& Wing Yan Man, T. (2012). The entrepreneurial behaviour inventory. International Journal of Entrepreneurial Behavior \& Research, 18(6), 673-696. doi: $10.1108 / 13552551211268120$
[30] Sadeghi, D., \& Esteki, M. (2011). Compare the state airlines and the private ones on their entrepreneurial characteristics of managers. Procedia-Social and Behavioral Sciences, 5(2), 2006-2011. doi: 10.1016/j.sbspro.2010.07.405

[31] Gerson, F. R., \& Machosky, B. (1993). Measuring customer satisfaction: A guide to managing quality service. (D. Woodbury, Ed.). Boston: Course Technology Crisp.

[32] Kotler, P. and Armstrong, G. (2010). Principles of marketing (13th ed.). Pearson Education.

[33] Martínez, P., del Bosque, I. R. (2013). CSR and customer loyalty: The roles of trust, customer identification with the company and satisfaction. International Journal of Hospitality Management, 35, 89-99. doi: 10.1016/j.ijhm.2013.05.009

[34] Houjeir, R., \& Brennan, D. (2017). The influence of culture on trust in B2B banking relationships. International Journal of Bank Marketing, 35(3), 495-515. doi: 10.1108/IJBM-05-2016-0075

[35] van Esterik-Plasmeijer, P. W. J., \& van Raaij, W. F. (2017). Banking system trust, bank trust, and bank loyalty. International Journal of Bank Marketing, 35(1), 97-111. doi:10.1108/IJBM-12-2015-0195

[36] Shukla, P., Banerjee, M., \& Singh, J. (2016). Customer commitment to luxury brands: Antecedents and consequences. Journal of Business Research. doi:10.1016/j.jbusres.2015.08.004

[37] Vyas, V., \& Raitani, S. (2014). Drivers of customers' switching behaviour in Indian banking industry. International Journal of Bank Marketing, 32(4), 321-342. doi:10.1108/IJBM-04-2013-0033

[38] Dimitriades, Z. S. (2006). Customer satisfaction, loyalty and commitment in service organizations. Management Research News, 29(12), 782-800. doi: 10.1108/01409170610717817

[39] Izogo, E. E. (2016). Antecedents of attitudinal loyalty in a telecom service sector: The Nigerian case. International Journal of Quality \& Reliability Management, 33(6), 747-768. doi: 10.1108/IJQRM-062014-0070

[40] Abu-ELSamen, A. A., Akroush, M. N., Al-Khawaldeh, F. M., \& AlShibly, M. S. (2011). Towards an integrated model of customer service skills and customer loyalty: The mediating role of customer satisfaction. International Journal of Commerce and Management, 21(4), 349-380. doi: 10.1108/10569211111189365

[41] Saleem, M. A., Zahra, S., Ahmad, R., \& Ismail, H. (2016). Predictors of customer loyalty in the Pakistani banking industry: A moderatedmediation study. International Journal of Bank Marketing, 34(3), 411-430. doi:10.1108/IJBM-12-2014-0172

[42] Mascarenhas, O. A., Kesavan, R., Bernacchi, M., Bowen, J. T., Chen, S.-L., Johnston, R., \& Kong, X. (2001). Lasting customer loyalty: a total customer experience approach. Journal of Consumer Marketing, 23(21), 397-405. doi: 10.1108/07363760610712939

[43] McMullan, R., \& Gilmore, A. (2008). Customer loyalty: An empirical study. European Journal of Marketing, 42(9/10), 1084-1094. doi: 10.1108/03090560810891154

[44] Izogo, E. E. (2017). Customer loyalty in telecom service sector: The role of service quality and customer commitment. The TQM Journal, 29(1), 19-36. doi: 10.1108/TQM-10-2014-0089

[45] Wang, R., Hempton, B., Dugan, J. P., \& Susan, R. (2008). Cultural differences: Why do asians avoid extreme responses? Survey Practice, 1(3), 1-7.

[46] Malhotra, N. K. (2010). Marketing research. (yagan sally, Ed.) (6th ed.). New Jersey: Pearson Education

[47] Andreini, D., Salo, J., Wendelin, R., Pezzotta, G., \& Gaiardelli, P. (2015). From a service-dominant logic to a good-dominant logic. IMP Journal, 9(3), 250-266. doi: 10.1108/IMP-07-2015-0034

[48] Brady, M.K. \& Cronin, J. (2001). Customer orientation : Effects on customer service perceptions and outcome behaviors. Journal of service Research, 3(3), 241-251. doi: 10.1177/109467050133005 